\section{DC-STAMP and TACE Levels are Higher in Patients with Periodontitis}

Cyro José de Almeida Guardiola ${ }^{1}$ (D) Juliana Trindade Clemente-Napimoga ${ }^{2}$ (D), Elizabeth Ferreira Martinez ${ }^{1}{ }^{\circ}$, Henrique Balassini Abdalla² ${ }^{\circ}$, Daiane Cristina Peruzzo $^{1}$ [D, Júlio César Joly ${ }^{1}$ (D), Marcelo Henrique Napimoga² (D)

\begin{abstract}
Although periodontitis is one of the commonest infectious inflammatory diseases in humans, the mechanisms involved with its immunopathology remain ill understood. Numerous molecules may induce inflammation and lead to bone resorption, secondary to activation of monocytes into osteoclasts. TACE (TNF- $\alpha$ converting enzyme) and DCSTAMP (dendritic cell-specific transmembrane protein) appear to play a role on bone resorption since TACE induces the release of sRANKL (soluble receptor activator of nuclear factor kappa- $\beta$ ligand) whereas DC-STAMP is a key factor in osteoclast induction. The present study evaluated the levels of TACE and DC-STAMP in patients with and without periodontitis. Twenty individuals were selected: 10 periodontally healthy participants undergoing gingivectomy for esthetic reasons and 10 diagnosed with periodontitis. Protein levels of such molecules in gingival tissue were established using Western blotting. Protein levels of both TACE and DC-STAMP were higher in the periodontitis group than in the control group ( $p<0.05$; Student t-test). In conclusion, TACE and DC-STAMP protein levels are elevated in patients with periodontitis, favoring progression of bone resorption.
\end{abstract}

'Periodontics and Implantology, Instituto de Pesquisas São Leopoldo Mandic, Faculdade São Leopoldo Mandic, Campinas, SP, Brazil ${ }^{2}$ Laboratory of Neuroimmune Interface of Pain Research Instituto de Pesquisas São Leopoldo Mandic, Faculdade São Leopoldo Mandic, Campinas, SP, Brazil

Correspondence: Marcelo $\mathrm{H}$. Napimoga, DDS, PhD, Rua José Rocha Junqueira, 13, 13045-755 Campinas, SP, Brasil. Tel.:+55-19-3211-3600. e-mail: marcelo.napimoga@gmail.com

Key Words: periodontitis, inflammation, TACE, DCSTAMP, bone resorption.

\section{Introduction}

Periodontitis is an infectious inflammatory disease characterized by destruction of teeth supporting structures, also reported to be a modifiable risk factor for numerous systemic conditions (1).

Several processes may contribute to the transition from a simple microbial community to a state of dysbiosis, which could lead to the onset and/or progression of periodontal disease. Changes to host immune competence may affect bacterial populations increasing production of virulence factors. As a bacterial community develops, microbial metabolism and immune response byproducts may modify the local environment facilitating the growth or predominance of microorganisms associated to dysbiosis (2). Evidence to support this comes, for example, from the discovery of a new virulence factor isolated from Porphyromonas gingivalis, namely phosphoglycerol dihydroceramide, which is a new class of lipids, capable of upregulating osteoclastogenesis in vitro and in vivo (3).

Although periodontitis is one of the commonest infection-driven human inflammatory diseases, yet the mechanisms leading to its immunopathology remain largely unknown. Numerous molecules have been described to play stage-specific roles on the inflammatory process that leads to bone loss. In the past two decades, the new field of "osteoimmunology" has revealed a deeply integrated immuno-skeletal interface in which cells from the immune system orchestrate both the physiological and pathological bone resorption and bone formation (4). The main molecules involved in such process are the receptor activator of nuclear factor kappa- $\beta$ ligand (RANKL), its antagonist osteoprotegerin (OPG) (5), cytokines like IL-1 $\beta$, IL-17 and TNF- $\alpha$ (6) and more recently, a new cytokine known as secreted osteoclastogenic factor of activated $\mathrm{T}$ cells (SOFAT) that induces osteoclastic bone resorption independently from RANKL $(7,8)$, which has also shown to be an important tissue marker of osteoclasts (9).

Under physiological conditions, there is a balance between osteoblastic and osteoclastic activity in order to ascertain constant bone renewal. Bone loss results therefore from an imbalance in osteoclastic bone resorption in relation to osteoblastic bone formation. Osteoclastogenic bone resorption is promoted primarily by the key osteoclastogenic cytokine, RANKL, and moderated physiologically by its antagonist, OPG (10). The importance of these two molecules in bone tissue today is well known, however, signaling for bone resorption and neoformation is much more complex and involves a number of other molecules in a complex mechanism, which is not yet fully elucidated. As for inflammatory mediators, increased expression of classic proinflammatory cytokines such as IL-1 $\beta$ and TNF- $\alpha$ (11), dysregulation between the IL-17 / IL-23 / FOXP3 axis (12), upregulated expression of IL-33 (13), the involvement of the Wnt- $\beta$-catenin pathway (14) and 
new mediators $(7,8)$ have shown that periodontal disease is a major puzzle of inflammatory mediators.

In order for bone resorption to occur, monocytes must be activated and fuse to become an osteoclast, with some molecules playing an important part in this process. TACE (TNF- $\alpha$ converting enzyme) has the ability to cleave the precursor of TNF- $\alpha$ to release active and soluble TNF- $\alpha$, which in turn cleaves mRANKL (RANKL anchored to the cell membrane) with release of sRANKL (RANKL), therefore TACE may play an effective role on promoting osteoclastogenesis in periodontitis (15). DC-STAMP (dendritic cell-specific transmembrane protein) is another potentially determinant molecule in this process, as it participates in osteoclast fusion, thus favoring osteoclast-induced bone destruction (16-18), though it does not seem to affect the adaptive immune response against oral bacteria (19).

Therefore, the main aim of this study was to evaluate the protein levels of TACE and DC-STAMP in gingival biopsies with or without periodontitis. Given the great interaction between different molecules in the context of osteoclastic activation, the present study evaluated the levels of TACE and DC-STAMP in patients with and without periodontitis since the role of such molecules in the development of bone lytic lesion in periodontal disease is still little explored. The null hypothesis tested was that there is no difference in DC-STAMP and TACE expression between individuals with and without periodontitis.

\section{Material and Methods}

Ten systemically healthy subjects with healthy gingival tissue and 10 systemically healthy individuals but with generalized periodontitis were selected from the population referred to the Instituto Rosenvaldo Moreira (Goiânia, GO, Brazil) from December 2017 until August 2018. Eligible individuals were invited to participate in the study, informed regarding the nature, potential risks and benefits of the study and signed their informed consent. During the screening of volunteers, medical and dental histories were obtained. This study protocol was approved by the Ethics Committee in Clinical Research of the Faculdade São Leopoldo Mandic (\# 2.431.548).

Subjects were $>30$ years of age, with generalized periodontitis (1) and presenting a minimum of 15 teeth, excluding third molars. Subjects were required to present $>30 \%$ of sites with probing depth (PD) and clinical attachment level (CAL) $\geq 4 \mathrm{~mm}$ and bleeding on probing (BoP) and a minimum of six teeth distributed across the four quadrants with at least one site showing PD and CAL $\geq 5 \mathrm{~mm}$ as well as BoP. The subjects were also required to have at least two teeth with indication for exodontia due to advanced periodontitis (sites with PD and CAL $\geq 7 \mathrm{~mm}$ with BoP, mobility and/or bone loss reaching more than half of the root), as previously described (14).

Exclusion criteria were pregnancy, lactation, current smoking, and smoking within the 5 years preceding the study, periodontal or/and antibiotic therapy in the previous 6 months, use of mouthrinses containing antimicrobials in the 2 months preceding the study, any systemic condition that could affect the progression of periodontal disease and the levels of the studied molecules [e.g. immunological disorders, diabetes mellitus, bone-related diseases, and complications, (e.g. osteoporosis, ankylosing spondylitis, recent bone fractures, and rheumatoid arthritis)] and long-term administration of anti-inflammatory agents (e.g. glucocorticoids), use of immunosuppressive medications, hormone replacement therapy, and antiresorptive agents (e.g. bisphosphonates and denosumab). Subjects wearing orthodontic appliances or presenting with periapical lesions related to endodontic disease were also excluded.

\section{Clinical Examinations}

A single examiner (CJAG), previously trained and calibrated on the established method (20) performed all clinical examinations. The following parameters were assessed at six sites for all teeth, excluding third molars (mesiobuccal, medio-buccal, disto-buccal, mesio-lingual, medio-lingual, distolingual), using a manual periodontal probe (UNC15; Hu-Friedy, Chicago, IL, USA): visible plaque accumulation $(\mathrm{PI})$ and marginal bleeding $(\mathrm{MB})(21)$, bleeding on probe $(\mathrm{BoP})$, pocket depth (PD) $(\mathrm{mm})$, and clinical attachment loss (CAL) (mm).

\section{Gingival Tissue Sampling}

This study was performed between December 2017 until August 2018. Twenty subjects ( 10 in the periodontitis group and 10 in the control group), ranging from 30 to 55 years of age $34.6 \pm 4.56$ and $41.5 \pm 8.97$ respectively, were selected out of almost 350 screened.

Gingival samples were collected 1 week after clinical examination so as to not alter the nature of the periodontal inflammatory process. For the periodontitis group, gingival tissue was collected from a tooth indicated for exodontia due to advanced periodontitis ( $P D$ and $C A L \geq 7 \mathrm{~mm}$ with BoP) to obtain representative areas of the periodontal inflammation. If the patient had two or more teeth with these characteristics, a gingival biopsy from one tooth was included, where the choice would be for the tooth with the worst clinical condition. For the healthy gingival tissue group, gingival biopsies were collected from a single tooth with no sign of clinical inflammation ( $P D \leq 3 \mathrm{~mm}$ without $\mathrm{BoP}$ and/or MB), but with indication for gingivoplasty for esthetic purposes. All gingival samples included junctional and sulcular epithelia and connective tissue. The gingival tissues were stored in protease inhibitor buffer (Sigma- 
Aldrich, St Louis, MO, USA) at $-80^{\circ} \mathrm{C}$ for Western blotting.

\section{Western Blotting}

Briefly, tissues were lysed and clarified by centrifugation and protein concentrations were determined using the bicinchoninic acid protein assay kit (Thermo Fisher Scientific, Waltham, MA, USA). Equal amounts of protein $(20 \mu \mathrm{g})$ from the gingival tissue were resolved by SDS-PAGE and transferred to polyvinylidene difluoride membranes. Immunoblotting of lysates was performed with antibodies for TACE and DC-STAMP (Bioss Antibodies, Woburn, MA, USA), or GAPDH (Cell Signaling Technology, Beverly, MA). After incubation with the appropriate secondary antibodies, proteins were visualized using Pierce ${ }^{\mathrm{TM}}$ ECL Plus Western Blotting Substrate (Thermo Fisher). Pixel intensities of immunoreactive bands were acquired using Image Quant LAS 4000 (General Electric, Boston, MA, USA). Banding specificity was determined by omission of the primary antibody from the Western-blotting protocol. A computerbased imaging system (Image J; National Institutes of Health, Bethesda, MD, USA) was used to measure the optical density intensity of the bands. umber of teeth/subjects selected for sampling was based on a previous study that found differences in immunoinflammatory protein levels, when comparing different clinical periodontal statuses (14). The statistical analyses were performed using a software program (GraphPad Prism 6.0, La Jolla, CA, USA). Data were first examined for normality by the Kolmogorov-Smirnov test. Non-parametric methods were used for data that did not achieve normality. The mean percentages of sites with visible plaque accumulation, BoP, the mean $\mathrm{PD}$, and $\mathrm{CAL}$ were computed for all teeth. Subsequently, the clinical parameters, the DC-STAMP and TACE protein levels were averaged for the periodontitis and non-periodontitis groups. The differences between the periodontitis and healthy gingival tissue groups, regarding the clinical parameters and age were compared using the unpaired $t$ test with Welch's correction. The differences between the periodontitis and healthy gingival tissue for the DC-STAMP and TACE protein were compared using the Student t-test.

\section{Results}

Table 1 presents the demographic characteristics of the study population and the clinical parameters of the sampled teeth and full-mouth. As expected, the levels of all 
stimulated NK cells increase TACE activity, significantly increasing TNF- $\alpha$ release (23). In patients with periodontal disease, TACE protein levels from gingival crevicular fluid were increased in groups with periodontitis (24). In addition, TACE increased RANKL protein expression and decreased OPG in osteoblasts favoring the progression of periodontitis (25). Besides, B cells have been shown to be the major cellular source of TACE and these activated lymphocytes play a key role on the conversion of membrane-coupled RANKL to generate soluble RANKL (15). The present study evaluated samples of periodontal tissue affected by periodontitis and presented significantly higher levels of TACE in the disease group. The fact that high levels were

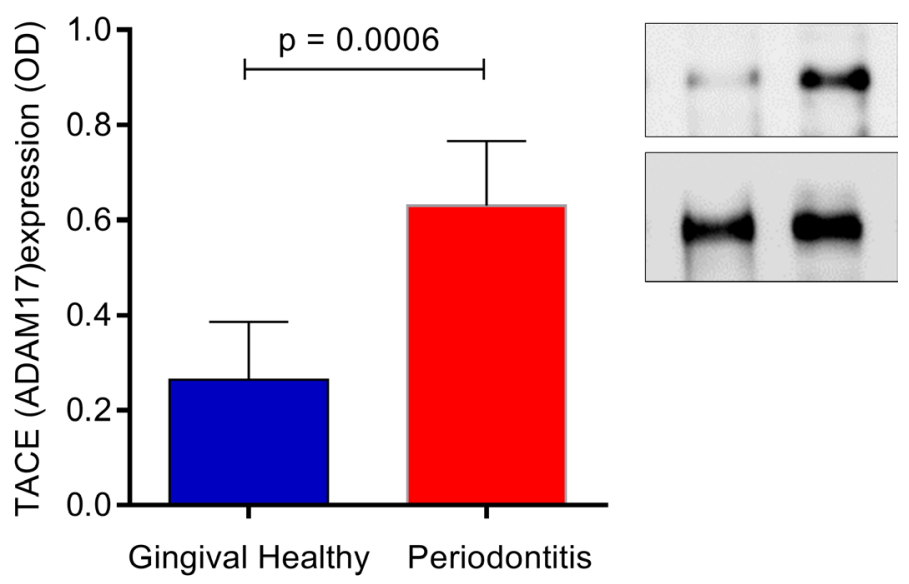

Figure 1. Protein expression of TACE in gingival healthy and periodontitis subjects. The data are represented by means \pm standard deviation (SD). It was observed statistical difference between both groups ( $p=0.0006$ ). Immunoblotting represents TACE (above) and GAPDH (below)

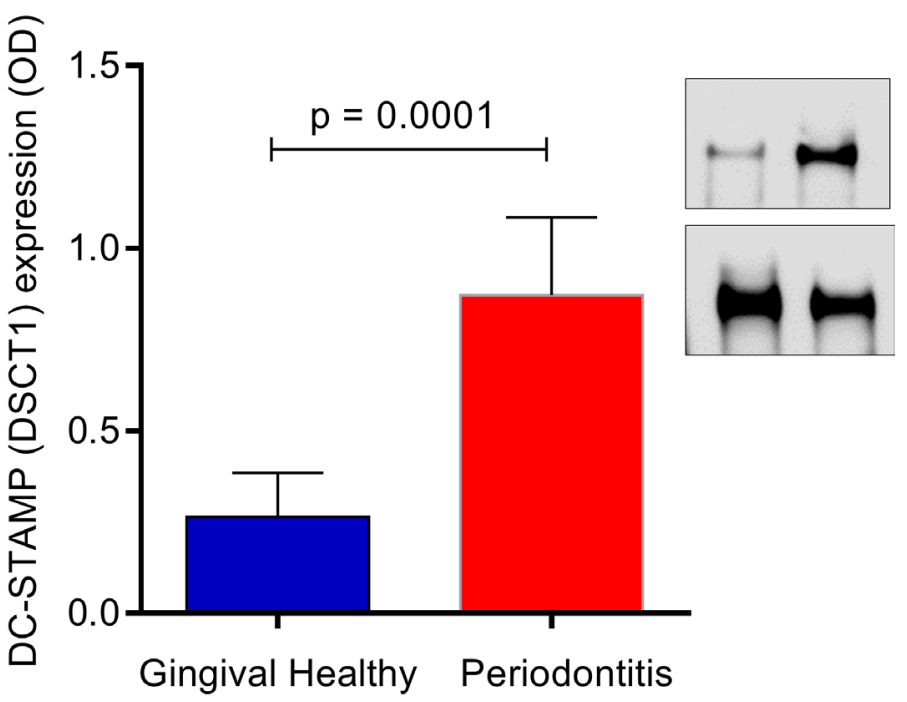

Figure 2. Protein expression of DC-STAMP in gingival healthy and periodontitis subjects. The data are represented by means \pm standard deviation (SD). It was observed statistical difference between both groups $(p=0.0001)$. Immunoblotting represents TACE (above) and GAPDH (below). found both in the crevicular fluid (25) and in periodontal tissue demonstrates that this molecule is involved in the process of osteoclastogenesis, since it also acts on the increase of TNF- $\alpha$ expression and consequently RANKL.

Identification of highly expressed dendritic cell-specific transmembrane protein (DC-STAMP) in multinucleated osteoclasts, but not in mononuclear precursors, was crucial for understanding how osteoclasts merge. Data from experiments on DC-STAMP-/- animals show decreased bone resorption compared to the wild type. Furthermore, DC-STAMP-/- animal osteoclast progenitor cells were transfected with retrovirus containing the DC-STAMP gene, which promoted fusion of osteoclast cells, indicating that DC-STAMP is a necessary molecule for this event to occur (16). Interestingly, systemic administration of anti-DC-STAMP monoclonal antibody was able to reduce alveolar bone loss induced by periodontal ligatures in animals. In addition, local injection of anti-DC-STAMP also suppressed alveolar bone loss and reduced the total number of multinucleated TRAP+ cells in mice that received periodontal ligatures (19).

Despite published evidence on the use of different products to inhibit bone resorption, including DC-STAMP $(26,27)$, this is the first study that evaluated the expression of this molecule in human gingival tissue with periodontitis. The present findings demonstrated a significant increase in DC-STAMP levels in gingival tissue of patients with periodontitis when compared with periodontally healthy individuals. Because of the infectious-inflammatory process installed in periodontitis, there is an increase in the influx of defense cells, including dendritic cells, which are important for antigen presentation. An increase in the number of these cells in the periodontal tissues would upregulate the expression of DC-STAMP, which in synergy with RANKL, are fundamental to initiate the differentiation and fusion of osteoclasts (18). In contrast to other studies that demonstrate this molecule in physiological scenarios (16), the present study suggests that the dysbiosis featured in periodontal disease may exacerbate the expression of DC-STAMP resulting in increased bone loss by increased activation of this pathway. The small sample size, was anticipated to be a limitation of the present study; however, both cytokines studied statistically differed between control and periodontitis groups. Therefore, new studies should analyze other molecules related to bone resorption, as well as the microbial profile present in periodontal patients for a better understanding 
of osteoimmunology.

In conclusion the data here demonstrate that the levels of TACE and DC-STAMP molecules is elevated in patients with periodontitis.

\section{Resumo}

Apesar de a periodontite ser uma das doenças infecto inflamatórias humanas mais comuns, os mecanismos que conduzem à imunopatologia não estão bem definidos. Inúmeras moléculas induzem atividade inflamatória que levam à perda óssea. Para que haja a reabsorção óssea, células monocíticas são ativadas e se transformam em osteoclastos. As moléculas TACE (Enzima conversora de TNF- $\alpha$ ) e DC-STAMP (Proteina transmembrana especifica de célula dendrítica) parecem atuar no processo de reabsorção óssea uma vez que a TACE induz a liberação de sRANKL (ativador do receptor do fator nuclear kappa- $\beta$ ligante solúvel), enquanto a DC-STAMP é um fator chave na indução dos osteoclastos. Diante disso, o presente estudo avaliou a expressão gênica das moléculas TACE e DC-STAMP em pacientes com e sem periodontite uma vez que o papel destas moléculas no curso do desenvolvimento da periodontite ainda é pouco explorado. Foram selecionados 20 indivíduos, sendo $10 \mathrm{com}$ saúde periodontal e com indicação para remoção de tecido gengival por motivos estéticos e 10 pacientes com periodontite. As análises da expressão das moléculas no tecido gengival foram realizadas por meio de western blotting. Os niveis proteicos tanto de TACE quanto de DC-STAMP, foram maiores nos tecidos do grupo com periodontite em comparação aos do grupo controle ( $p<0.05$; Student' t-test). Portanto, os dados demonstram que a expressão protéica das moléculas TACE e DC-STAMP estão elevados - em pacientes com periodontite, favorecendo a progressão da reabsorção óssea nesta patologia.

\section{Acknowledgements}

This work was supported by Conselho Nacional de Desenvolvimento $\therefore$ Científico e Tecnológico (CNPq) - Research Productivity Fellowship to - MHN and EFM and Coordenação de Aperfeiçoamento de Pessoal de Nivel Superior (CAPES).

\section{References}

1. Papapanou PN, Sanz M, Buduneli N, Dietrich T, Feres M, Fine DH, et al. Periodontitis: consensus report of workgroup 2 of the 2017 world workshop on the classification of periodontal and peri-implant diseases and conditions. J. Periodontol 2018;89:S173-S182.

2. Lamont RJ, Koo $H$, Hajishengallis $G$. The oral microbiota: dynamic communities and host interactions. Nat Rev Microbiol 2018;16:745759 .

3. Kanzaki H, Movila A, Kayal R, Napimoga MH, Egashira K, Dewhirst

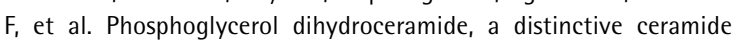
produced by Porphyromonas gingivalis, promotes RANKL-induced osteoclastogenesis by acting on non-muscle myosin II-A (Myh9), an osteoclast cell fusion regulatory factor. Biochim Biophys Acta Mol Cell Biol Lipids 2017;1862:452-462.

4. Weitzmann MN, Ofotokun I. Physiological and pathophysiological bone turnover - role of the immune system. Nat Rev Endocrinol 2016;12:518-532.

5. Lacey DL, Timms E, Tan HL, Kelley MJ, Dunstan CR, Burgess T, Elliott R, et al. Osteoprotegerin ligand is a cytokine that regulates osteoclast differentiation and activation. Cell 1998;93:165-176.

6. Weitzmann MN. Bone and the Immune System. Toxicol Pathol 2017:45:911-924.

7. Jarry CR, Duarte PM, Freitas FF, de Macedo CG, Clemente-Napimoga JT, Saba-Chujfi E, et al. Secreted osteoclastogenic factor of activated T cells (SOFAT), a novel osteoclast activator, in chronic periodontitis. Hum Immunol 2013;74:861-866.

8. Jarry CR, Martinez EF, Peruzzo DC, Carregaro V, Sacramento LA, Araújo
VC, et al. Expression of SOFAT by T- and B-lineage cells may contribute to bone loss. Mol Med Rep 2016;13:4252-4258.

9. Cândido-Soares LE, Martinez EF, de Araújo VC, Araújo NS, Freitas NS, Napimoga MH. SOFAT as a putative marker of osteoclasts in bone lesions. App Immunohistochem Mol Morphol 2019;27:448-453.

10. Teitelbaum SL. Bone resorption by osteoclasts. Science 2000;289:15041508.

11. Silva TA, Garlet GP, Fukada SY, Silva JS, Cunha FQ. Chemokines in oral inflammatory diseases: apical periodontitis and periodontal disease. $J$ Dental Res 2007;86:306-319.

12. Duarte PM, Santos VR, Dos Santos FA, de Lima Pereira SA, Rodrigues $\mathrm{DB}$, Napimoga MH. Role of smoking and type 2 diabetes in the immunobalance of advanced chronic periodontitis. J Periodontol 2011;82:429-438.

13. Köseoglu S, Hatipoglu M, Saglam M, Enhos S, Esen HH. Interleukin-33 could play an important role in the pathogenesis of periodontitis. J Periodontal Res 2015;50:525-534.

14. Napimoga $\mathrm{MH}$, Nametala $\mathrm{C}$, da Silva $\mathrm{FL}$, Miranda $\mathrm{TS}$, Bossonaro $J P$, Demasi AP, et al. Involvement of the Wnt- $\beta$-catenin signalling antagonists, sclerostin and Dickkopf-related protein 1 , in chronic periodontitis. J Clin Periodontol 2014;41:550-557.

15. Kanzaki $H$, Makihira $S$, Suzuki M, Ishii T, Movila A, Hirschfeld J, et al. Soluble RANKL cleaved from activated lymphocytes by TNF- $\alpha$ converting enzyme contributes to osteoclastogenesis in periodontitis. J Immunol 2016;197:3871-3883.

16. Yagi M, Miyamoto T, Sawatani $Y$, Iwamoto $K$, Hosogane $N$, Fujita $N$, et al. DC-STAMP is essential for cell-cell fusion in osteoclasts and foreign body giant cells. J Exp Med 2005;202:345-351.

17. Xing L, Xiu Y, Boyce BF. Osteoclast fusion and regulation by RANKLdependent and independent factors. World J Orthoped 2012;18:212222.

18. Zhang C, Dou CE, Xu J, Dong S. DC-STAMP, the key fusion-mediating molecule in osteoclastogenesis. J Cell Physiol 2014;229:1330-1335.

19. Wisitrasameewong W, Kajiya M, Movila A, Rittling S, Ishii T, Suzuki M, et al. DC-STAMP is an Osteoclast Fusogen Engaged in Periodontal Bone Resorption. J Dental Res 2017;96:685-693.

20. Araujo MW, Hovey KM, Benedek JR, Grossi SG, Dorn J, WactawskiWende J, et al. Reproducibility of probing depth measurement using a constant-force electronic probe: analysis of inter- and intraexaminer variability. J Periodontol 2003;74:1736-1740.

21. Ainamo J, Bay I. Problems and proposals for recording gingivitis and plaque. Int Dent J 1975;25:229-235.

22. Chemaly $M$, McGilligan V, Gibson $M$, Clauss $M$, Watterson $S$, Alexander $H D$, et al. Role of tumour necrosis factor alpha converting enzyme (TACE/ADAM17) and associated proteins in coronary artery disease and cardiac events. Arch Cardiovasc Dis 2017:110:700-711.

23. Sharma N, Trinidad CV, Trembath AP, Markiewicz MA. NKG2D signaling between human NK cells enhances TACE-mediated TNF- $\alpha$ release. J Immunol 2017;199:2865-2872.

24. Bostanci N, Emingil G, Afacan B, Han B, Ilgenli T, Atilla G, et al. Tumor necrosis factor-alpha-converting enzyme (TACE) levels in periodontal diseases. J Dental Res 2008;87;273-277.

25. Lee JH, Choi YJ, Heo SH, Lee JM, Cho JY. Tumor necrosis factor- $\alpha$ converting enzyme (TACE) increases RANKL expression in osteoblasts and serves as a potential biomarker of periodontitis. BMB Rep 2011:44:473-477.

26. An J, Hao D, Zhang $Q$, Chen B, Zhang $R$, Wang $Y$, et al. Natural products for treatment of bone erosive diseases: The effects and mechanisms on inhibiting osteoclastogenesis and bone resorption. Int Immunopharmacol 2016;36:118-131.

27. Choo YY, Tran PT, Min BS, Kim O, Nguyen HD, Kwon SH, et al. Sappanone A inhibits RANKL-induced osteoclastogenesis in BMMs and prevents inflammation-mediated bone loss. Int Immunopharmacol 2017:52:230-237. 